\title{
PERHITUNGAN PROPORSI PADA CANDI TEBING GUNUNG KAWI DI TAMPAKSIRING-GIANYAR
}

\author{
Anak Agung Gede Raka Gunawarman \\ Jurusan Arsitektur Fakuktas Teknik Universitas Warmadewa \\ arkadesignbali@gmail.com \\ I Kadek Merta Wijaya \\ Jurusan Arsitektur Fakuktas Teknik Universitas Warmadewa \\ amritavijaya@gmail.com
}

\begin{abstract}
Abstrak
Candi tebing merupakan salah satu karya arsitektur candi, yang dapat dikaji dan diteliti dari prinsip perancangan arsitekturnya salah satunya adalah dengan meneliti bagaimana perhitungan proporsinya. Candi Tebing Gunung Kawi sebagai peninggalan arsitektur candi di daerah aliran sungai Pakerisan juga bisa dijadikan sebagai sebuah objek penelitian dengan mengkaji bagaiamana perhitungan proporsi sepuluh candi tebing yang ada di kawasan tersebut. Tujuan penelitian ini tidak lain adalah untuk mencari bagaimana perhitungan proporsi pada perancangan Candi Tebing Gunung Kawi di Tampaksiring,Gianyar. Penelitian ini menggunakan metode penelitian mixed methods dan menggunakan metode field research atau penelitian lapangan.

Elemen pembentuk proporsi (EPP) pada Candi Tebing Gunung Kawi secara garis besar terbagi menjadi tiga bagian utama yaitu kaki, badan dan kepala. Detail EPP setiap bagian kaki, badan dan kepala masing-masing terdiri dari perbingkaian bawah, tubuh dan perbingkaian atas. Hasil dan pembahasan pada perhitungan proporsi candi menunjukan hasil bahwa tinggi keseluruhan candi adalah 2 kali lebar kaki (Lk) atau bisa juga 2 kali tinggi kepala (Tkp). Dalam teori manasara-silpasastra berkaitan dengan proporsi antar lebar dan tinggi terdapat lima pembagian perhitungan proporsi yaitu santika, paushtika, parshnika/jayada, adbhuta, dan sarvakamika (Acharya, 1927:41). Berdasarkan teori tersebut dapat disimpulkan pula bahwa perhitungan proporsi antara lebar dan tinggi pada Candi Tebing Gunung Kawi termasuk ke dalam paushtika.
\end{abstract}

Kata Kunci: candi tebing, elemen pembentuk, proporsi

\begin{abstract}
Candi Tebing is one of the architectural object, that can be reviewed and researched by design principal of its architecture is with doing reseach how to calculate its proportion. Candi Tebing Gunung Kawi as one of the architecture temple relic in Pakerisan watershed can be used as an architectural reseacrh object with review how yo calculate the proportion of ten candi that we can find at that area. The purpose of the research is to analyze its element and proportion calculation of the Candi Tebing Gunung Kawi design. The research design using mixed methods between qualitative and quantitative approaches, and also used field research method.

Proportion forming elements of Candi Tebing Gunung Kawi generally can be divided into three main parts; pedestal, body, and head. Each proportion forming elements detail on pedestal, body and crown, consist of a lower framed, body and upper framed. The result on the proportion calculation showed the proportion of temple's height twice the width of the pedestals (LK) or it could be twice of the crown width (the scene). Manasara-silpasastra theory explained the proportion between width and height calculation can be divided into five parts, those are; santika, paushtika, parshnika / jayada, adbhuta, and sarvakamika (Acharya, 1927:41). The conclusion based on that theory, Candi Tebing Gunung Kawi proportion between width and height classified into paushtika.
\end{abstract}

Keywords: candi tebing, forming elements, proportion 


\section{Pendahuluan}

Candi tebing merupakan salah satu karya arsitektur candi, yang dapat dikaji dan diteliti dari prinsip perancangan arsitekturnya salah satunya adalah dengan meneliti bagaimana perhitungan proporsinya. Candi Tebing Gunung Kawi sebagai peninggalan arsitektur candi di daerah aliran sungai Pakerisan juga bisa dijadikan sebagai sebuah objek penelitian dengan mengkaji bagaiamana perhitungan proporsi sepuluh candi tebing yang ada di kawasan tersebut. Tujuan penelitian ini tidak lain adalah untuk mencari bagaimana perhitungan proporsi pada perancangan Candi Tebing Gunung Kawi di Tampaksiring, Gianyar. Proporsi tentunya terbentuk dari hasil perbandingan dari satu elemen dengan elemen lain pada sebuah bangunan. Perbandingan tersebut bisa berupa pebandingan antara lebar, tebal dan tinggi tiap elemen. Candi-candi tebing di Gunung Kawi terlihat memiliki proporsi yang sama, namun untuk mengetahui bagaimana perhitungan dan dasar ukuran yang digunakan dalam menyusun proporsi tersebut tidak bisa dilihat dengan mata telanjang. Jika diperhatikan secara seksama candi-candi ini memiliki ukuran dan detail susunan yang berbeda-beda.

Perbedaan dari ukuran candi nampak pada candi kelompok lima yang mempunyai satu candi dengan ukuran lebih tinggi dari candi yang lain. Hal ini juga ditegaskan dalam arsip berupa gambar dari Balai Pelestarian Cagar Budaya (BPCB) yang juga memperlihatkan perbedaan-perbedaan tersebut. Perbedaan ini tentu menimbulkan pertanyaan apakah semua candi memiliki perhitungan proporsi yang sama. Perhitungan proporsi Candi Tebing Gunung Kawi menjadi menarik untuk diteliti dari penerapan sistem proporsi, karena candi tebing ini memiliki lokasi pendirian yang berbeda dari candi-candi pada umumnya yang didirikan diatas lahan datar dan bukan menempel pada dinding tebing.

Tujuan dari penelitian ini adalah untuk menganalisis elemen-elemen pembentuk proporsi (EPP) dan mengetahui perhitungan proporsi pada perancangan Candi Tebing Gunung Kawi di Tampaksiring, Gianyar. Penelitian ini diharapkan bisa menambah pedoman terkait dengan patokan ukuran proporsi yang digunakan dalam bangunan candi, khususnya pada Candi Tebing Gunung Kawi dan hasil temuan dari penelitian ini diharapkan bisa menjadi sebuah acuan maupun pembanding dalam perhitungan ukuran untuk membuat proporsi bangunan yang lain terkait dengan sikut, gegulak maupun asta kosala kosali khususnya pada arsitektur tradisional Bali.

\section{Metode}

Penelitian ini menggunakan metode penelitian mixed methods atau metode penelitian gabungan, yaitu perpaduan antara pendekatan kualitatif dan kuantitatif. Strategi penelitian menggunakan pengumpulan data secara simultan dan sequensial untuk memahami permasalahan dengan sebaik-baiknya. Pengumpulan data bisa diperoleh dari informasi numerik (melalui instrument) maupun informasi teks (melalui wawancara) sehingga data-data akhir yang diperoleh bisa memperlihatkan informasi yang bersifat kualitatif maupun kuantitatif (Emzir, 2012:28).

Penelitian ini juga menggunakan metode field research atau penelitian lapangan. Pendekatan field research dipilih karena pendekatan ini lebih cenderung kepada 
pengamatan mendalam di lapangan terhadap sebuah objek mengingat penelitian ini berkaitan dengan proporsi, sehingga perlua adanya pengukuran langsung dimensi obyek di lapangan. Data primer akan lebih mudah dikumpulkan dengan pengukuran pada obyek candi-candi tebing di Gunung Kawi. Permasalahan dan pertanyaan terhadap sebuah objek akan mudah ditemukan dengan observasi langsung dilapangan.

Penentuan sumber data penelitian merupakan acuan untuk menentukan intrumen dan teknik pengumpulan data yang sesuai. Penelitian ini menggunakan data-data kuantitatif dan kualitatif yang dikumpulkan dengan cara melakukan pengukuran obyek candi tebing dan wawancara dengan narasumber terkait. Untuk teknik pengumpulan data kuantitatif tentunya dilakukan dengan pengukuran langsung pada candi tebing dengan membagi bagian candi tebing menjadi tiga yaitu kepala, badan dan kaki. Alat ukur yang digunakan dalam pengukuran adalah meteran manual, mengingat medan yang cukup sulit dan kondisi candi yang sudah dalam keadaan tidak baik.

\section{Hasil dan Pembahasan}

\subsection{Gambaran Umum Candi Tebing Gunung Kawi}

Candi Tebing Gunung Kawi berada di Dusun Penaka, Desa Tampaksiring, Kecamatan Tampaksiring, Kabupaten Gianyar. Candi Tebing Gunung Kawi terdiri dari 10 buah candi yang terletak di tiga lokasi seperti penjelasan pada pada Gambar 1. Candi-candi tebing di Gunung Kawi memiliki genah pedagingan yang terletak tepat di bawah pintu semu. Genah pedagingan adalah tempat untuk menguburkan atau menyimpan lima macam jenis logam yang disimbolkan sebagai lima dasar kemuliaan saat ritual mapendeman panca datu (Disbud, 1987: 6). Peti nawasanga adalah tempat untuk meletakkan berbagai jenis logam dan benda lainnya yang disertai dengan saji-sajian. Benda-benda inilah yang juga disebut dengan pripih (Soekmono, $1988: 81$ ). 


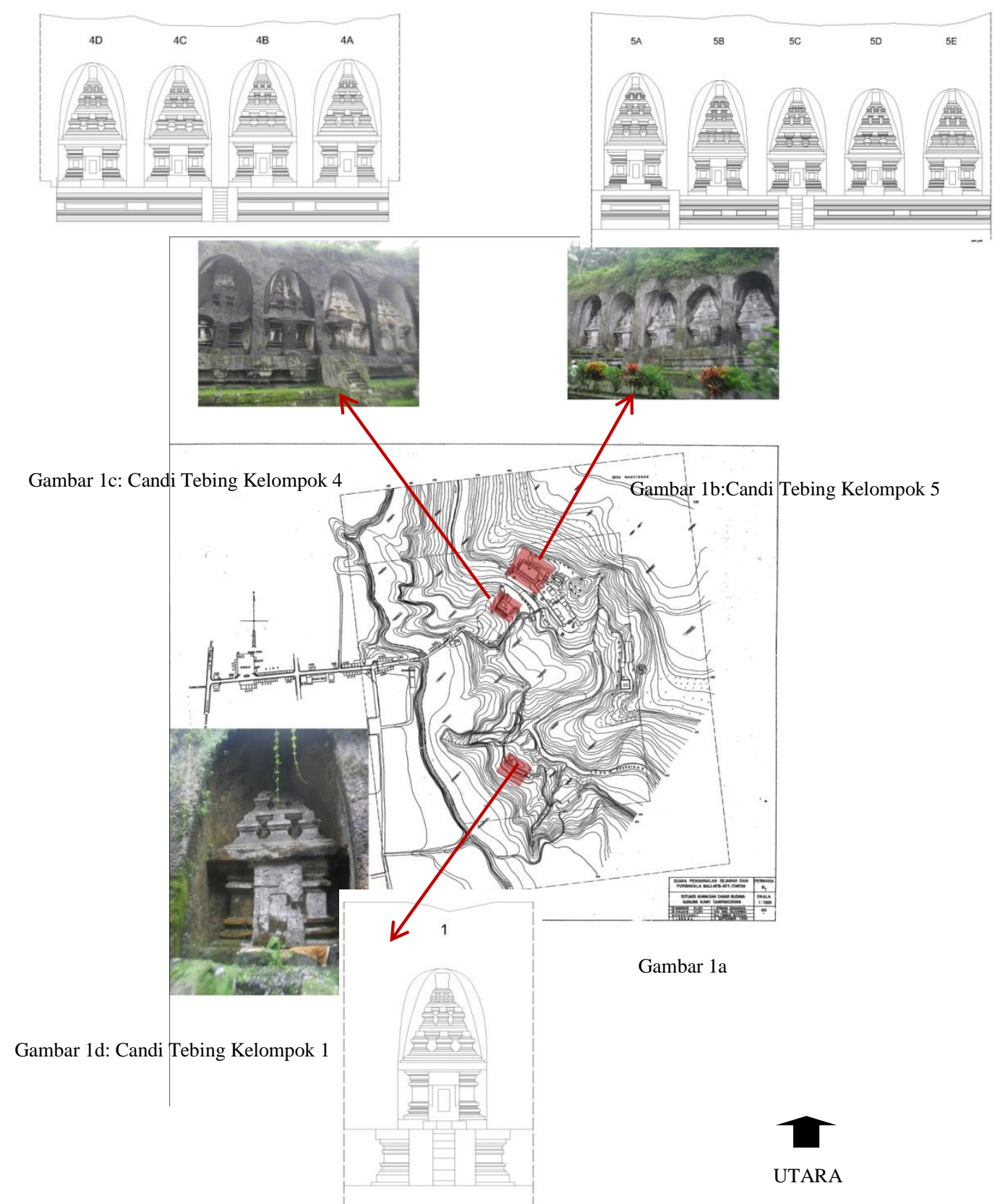

\section{Gambar 1a. Peta Situasi Candi Tebing Gunung Kawi Sumber : Dokumentasi BPCB, 1996}

Gambar 1b-1d. Tampak Depan Candi Tebing Gunung Kawi Sumber : Dokumentasi Gunawarman, 2017

Candi-candi Tebing Gunung Kawi berada di sisi kanan dan kiri Sungai Pakerisan, begitu pula goa-goa pertapaan yang tersebar disepanjang aliran sungai. Candi kelompok 5 dan kelompok 4 posisinya saling berhadapan dan kedua kelompok ini ada di sisi kanan kiri aliran sungai. Berbeda halnya dengan candi 5 dancandi 4 yang berkelompok, candi 1 hanya terdiri dari satu candi dan berada jauh di selatan candi 5 dan candi 4 . Secara umum kondisi fisik dari sepuluh candi ini sudah mulai mengalami kerusakan. Hal ini tampak jelas pada candi-candi kelompok 4, terutama candi 4D yang kondisinya sudah sangat memprihatinkan. Bagian kepala candi 4D hampir sudah tidak berbentuk pada bagian depan, begitu pula yang terjadi pada bagian kepala candi 1 . Kerusakan-kerusakan pada muka candi juga menyulitkan proses pengukuran untuk mendapatkan perhitungan proporsi candi. 
Bentuk-bentuk asli candi juga sulit dipastikan mengingat candi-candi sudah pernah dilapisi dengan semen untuk menjaga bentuk candi. Kerusakan umumnya terjadi pada sisi depan candi, sedangkan pada bagian-bagian samping masih bisa terbaca dan dapat diukur.

\subsection{Elemen-Elemen Pembentuk Proporsi (EPP) pada Candi Tebing Gunung Kawi}

Proporsi pada candi tebing Gunung Kawi dibentuk oleh tiga elemen utama yaitu kaki, badan dan kepala. Setiap elemen utama juga disusun oleh elemen-elemen penyusun yang lebih detail sehingga terbentuklah proporsi pada candi tebing tersebut. Untuk mempermudah dalam memberikan penjelasan, elemen-elemen detail tersebut diberi nama elemen pembentuk proporsi dengan kode EPP. Masing-masing candi di setiap kelompok memiliki pengulangan EPP yang hampir sama, namun ada beberapa bagian yang berbeda. EPP akan dibahas dalam setiap elemen utama candi yaitu pada kaki, badan dan kepala.

Proporsi Candi Tebing Gunung Kawi juga dibentuk oleh EPP yang sangat detail dari bagian-bagian terkecil. Pemberian nama pada setiap EPP disesuaikan dengan pemberian nama di daerah Gianyar mengingat Candi Tebing Gunung Kawi masih berada di kawasan Gianyar dan melakukan wawancara pada narasumber yang tahu tentang penamaan bagian candi. Para narasumber yang diwawancarai berasal dari BPCB, undagi, dan tukang stil Bali yang ada di seputaran wilayah Tampaksiring Gianyar. Hal ini bertujuan untuk memberikan komparasi dan mencari kesesuaian nama-nama EPP yang akan digunakan.

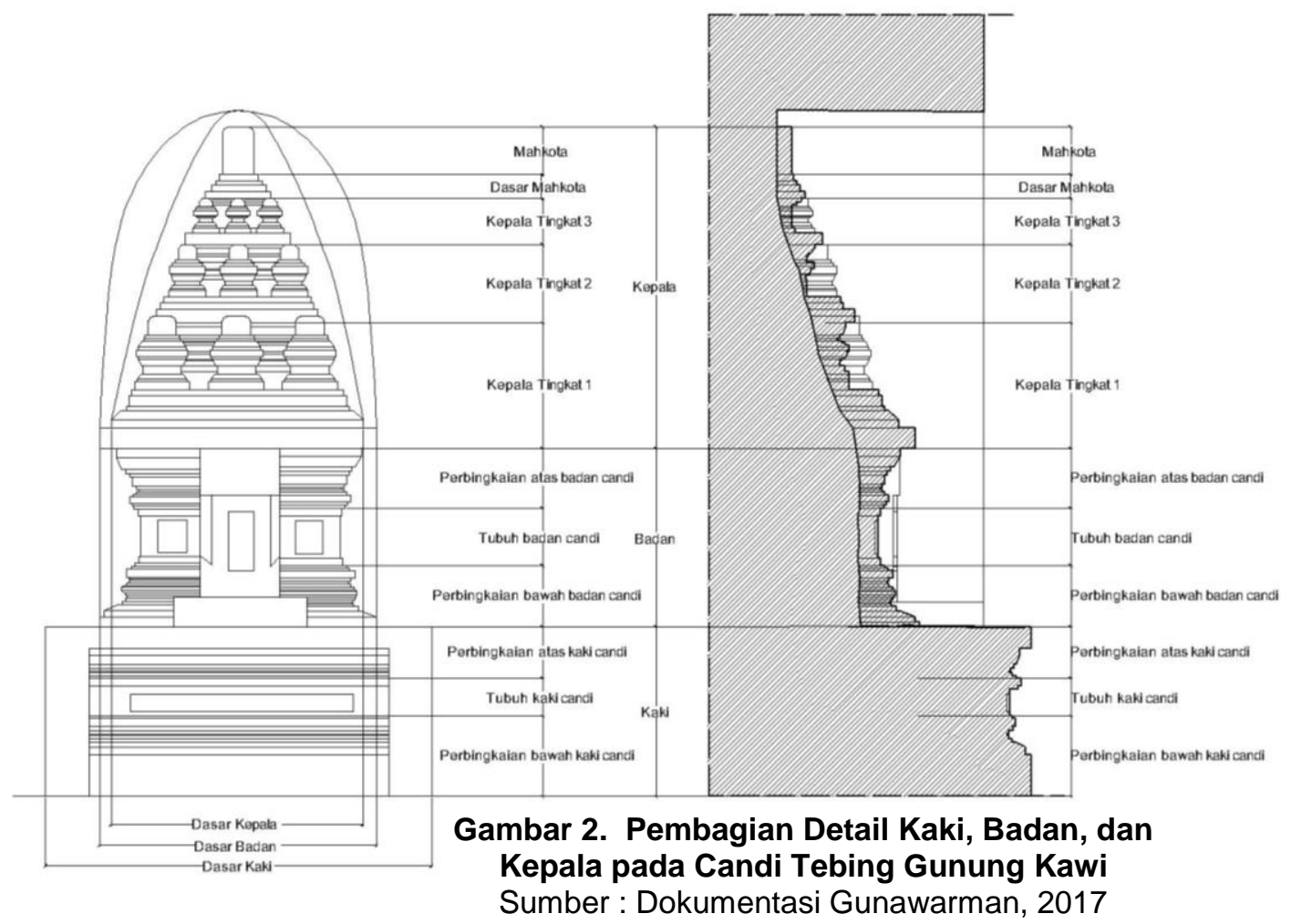

\subsection{Perhitungan Proporsi pada Candi Tebing Gunung Kawi}

Tampak depan sebagai patokan utama dalam menentukan bagaimana perhitungan proporsi pada Candi Tebing Gunung Kawi. Ukuran dari setiap elemen 
pembentuk proporsi yang bisa dibanding-bandingkan antara lain seperti tinggi kaki candi (Tk), tinggi badan candi (Tb), tinggi kepala candi (Tkp), tinggi pintu semu $(T p)$, lebar pintu semu (Lp), tinggi keseluruhan (T), lebar dasar kaki (Lk), lebar dasar badan (Lb), dan lebar dasar kepala (Lkp).

Dimensi elemen-elemen tersebut adalah dimensi EPP untuk perbandingan proporsi secara global, namun pada bagian kepala mempunyai EPP yang lebih mendetail dan harus dianalisis. Bagian kepala candi memiliki tiga tingkatan sehingga ukuran setiap tingkatan pada bagian kepala dapat dibandingkan juga terhadap tinggi kepala candi. Perbandingan ini bertujuan untuk mendapatkan perhitungan khusus pada bagian kepala candi. Pembagian ukuran tersebut adalah tinggi kepala tingkat 1 (Tkp1), tinggi kepala tingkat 2 (Tkp2), tinggi kepala tingkat 3 (Tkp3), tinggi dasar mahkota (Tdm), dan tinggi mahkota (Tm). Penjelasan dari elemen-elemen yang dibandingkan tersebut dapat dilihat pada Gambar 12.

\section{Keterangan}

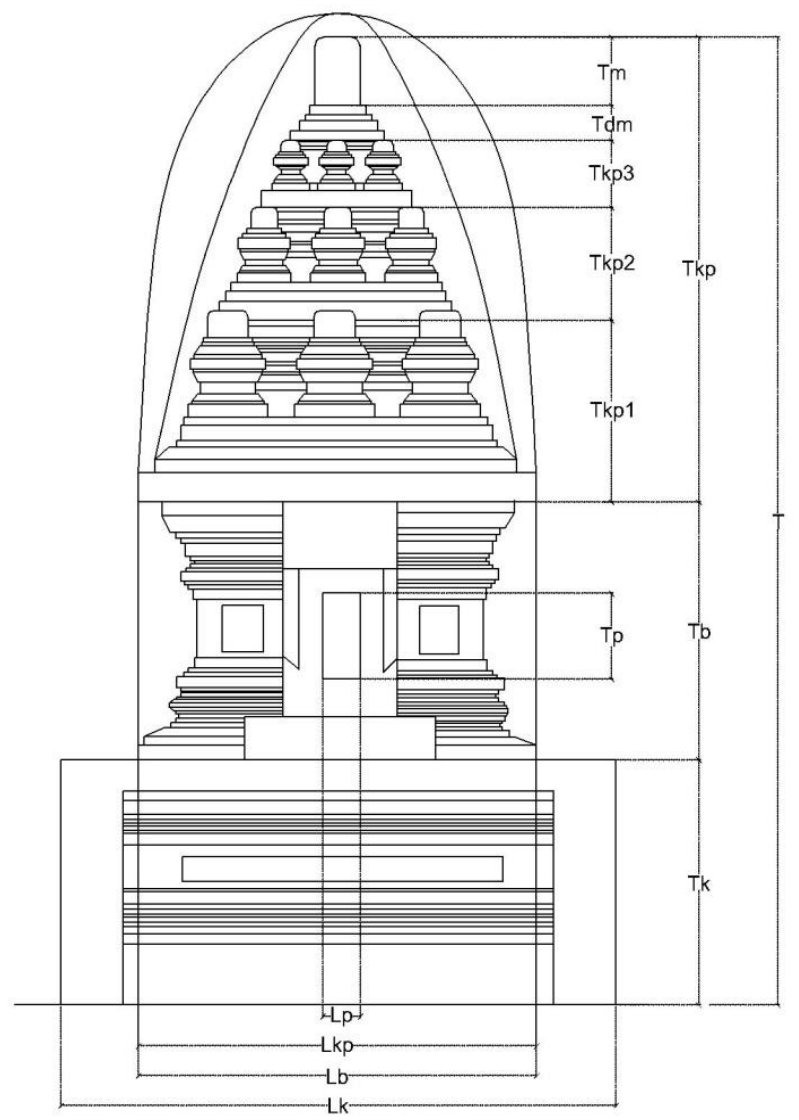

T : tinggi keseluruhan candi, Tk : tinggi kaki candi, Tb : tinggi badan candi, Tkp: tinggi kepala candi, Tkp1: tinggi kepala tingkat 1, Tkp2: tinggi kepala tingkat 2, Tkp3: tinggi kepala tingkat 3 , Tdm: tinggi dasar mahkota, Tm: tinggi mahkota, Tp : tinggi pintu semu, Lp : lebar pintu semu, Lk : lebar dasar kaki candi, Lb : lebar dasar badan candi, Lkp :

\section{Gambar 3. Kode EPP Candi yang dianalisa untuk perhitungan proporsi} Sumber : Dokumentasi Gunawarman, 2013

Ukuran dari elemen-elemen pembentuk proporsi Candi Tebing Gunung Kawi didasarkan pada hasil pengukuran yang sudah dilakukan pada proses sebelumnya. Perhitungan dan perbandingan yang bisa dianalisis dari tampak depan bangunan Candi Tebing Gunung Kawi adalah Tk:T, Tb:T, Tkp:T, Tp:T, Lk:T, 
Lb:T, Lkp:T, Lp:T, Tk:Lk, Tb:Lb, Tkp:Lkp, Lp:Tp, Tkp1:Tkp, Tkp2:Tkp, Tkp3:Tkp, Tdm:Tkp dan Tm:Tkp. Perbandingan ini juga mengacu pada hasil penelitian dari Atmadi pada penelitiannya terhadap bangunan susunan batu di relief Candi Borobudur yang juga hanya memiliki satu muka saja. Beberapa perbandingan juga dianalisis untuk memperbanyak hasil temuan yang bisa dibandingkan sehingga bisa ditarik satu kesimpulan.

Tabel 1 menjelaskan tentang dimensi setiap EPP dengan satuan $\mathrm{cm}$. Tinggi keseluruhan candi dari bagian kaki hingga kepala pada candi 5 dan candi 4 berkisaran $\pm 1000 \mathrm{~cm}$ atau $10 \mathrm{~m}$, sedangkan pada candi 1 jauh lebih pendek yaitu $\pm 800 \mathrm{~cm}$ atau $8 \mathrm{~m}$. Perbedaan dimensi yang signifikan memang terjadi pada candi 1 baik dari dimensi keseluruhan maupun dimensi setiap EPP. Kerusakankerusakan yang berbeda disetiap candi juga menjadi permasalahan dalam menentukan dimensi yang sebenarnya, oleh sebab itu penentuan koefisien ratarata di setiap dimensi EPP perlu ditentukan. Candi 5 dan candi 4 hampir memiliki dimensi yang tidak jauh berbeda sehingga bisa ditentukan koefisien rata-ratanya.

Tabel 1. Dimensi EPP Candi Tebing Gunung Kawi

\begin{tabular}{|l|l|l|l|l|l|l|l|l|l|}
\hline \multirow{2}{*}{$\begin{array}{l}\text { Kode } \\
\text { Candi }\end{array}$} & \multicolumn{10}{|c|}{ T } & Tk & Tb & Tkp & \multicolumn{1}{|c|}{ Tp } & Lp & Lk & Lb & Lkp \\
\hline 5A & 1128.5 & 286 & 300.5 & 542 & 100 & 44 & 652 & 468 & 468 \\
\hline 5B & 1069 & 250 & 287.5 & 531.5 & 93 & 45 & 579.5 & 445 & 445 \\
\hline 5C & 1023 & 250 & 271 & 502 & 95 & 44 & 580 & 440 & 440 \\
\hline 5D & 1013 & 250 & 276.5 & 486.5 & 100 & 43 & 579.5 & 439 & 439 \\
\hline 5E & 1023.5 & 250 & 280 & 493.5 & 99 & 45 & 570 & 434 & 434 \\
\hline 4A & 1046 & 228 & 303 & 515 & 80 & 48 & 555 & 453 & 453 \\
\hline 4B & 1046.5 & 228 & 299 & 519.5 & 95 & 47 & 559.5 & 449.5 & 449.5 \\
\hline 4C & 1007 & 228 & 284.5 & 494.5 & 84 & 44 & 559.5 & 444 & 444 \\
\hline 4D & 1026.5 & 228 & 279.5 & 519 & 87 & 44 & 522 & 450 & 450 \\
\hline 1 & 808 & 214 & 226 & 368 & 83 & 39 & 488 & 303.5 & 303.5 \\
\hline Rata- & & & & & & & & & \\
rata & $\mathbf{1 0 1 9}$ & $\mathbf{2 4 1}$ & $\mathbf{2 8 1}$ & $\mathbf{4 9 7}$ & $\mathbf{9 2}$ & $\mathbf{4 4}$ & $\mathbf{5 6 5}$ & $\mathbf{4 3 3}$ & $\mathbf{4 3 3}$ \\
\hline
\end{tabular}

Tabel 2 dan Tabel 3 menjelaskan tentang perhitungan dari setiap EPP yang memungkinkan jika dilihat dari tampak bangunan. Perbandingan EPP pada Tabel 2 juga mengacu pada perhitungan proporsi yang dilaksanakan oleh Atmadi. Tinggi candi secara keseluruhan menjadi patokan dalam menentukan apa saja yang dibandingkan, sehingga setiap EPP akan dibandingkan dengan tinggi candi secara keseluruhan. 
Tabel 2. Perhitungan proporsi Candi Tebing Gunung Kawi

\begin{tabular}{|c|c|c|c|c|c|c|c|c|c|}
\hline \multirow{2}{*}{$\begin{array}{l}\text { Kode } \\
\text { Candi }\end{array}$} & \multicolumn{9}{|c|}{ Perhitungan } \\
\hline & $\begin{array}{c}T / T \\
k\end{array}$ & $\mathrm{~T} / \mathrm{Tb}$ & $\begin{array}{c}\text { T/Tk } \\
\mathbf{p}\end{array}$ & T/Lk & T/Lb & $\begin{array}{c}\text { T/Lk } \\
\mathbf{p}\end{array}$ & T/Tp & T/Lp & $\begin{array}{c}T p / L \\
p\end{array}$ \\
\hline $5 \mathrm{~A}$ & 3.9 & 3.8 & 2.1 & 1.7 & 2.4 & 2.4 & 11.3 & 25.6 & 2.3 \\
\hline $5 B$ & 4.3 & 3.7 & 2.0 & 1.8 & 2.4 & 2.4 & 11.5 & 23.8 & 2.1 \\
\hline $5 \mathrm{C}$ & 4.1 & 3.8 & 2.0 & 1.8 & 2.3 & 2.3 & 10.8 & 23.3 & 2.2 \\
\hline $5 \mathrm{D}$ & 4.1 & 3.7 & 2.1 & 1.7 & 2.3 & 2.3 & 10.1 & 23.6 & 2.3 \\
\hline $5 \mathrm{E}$ & 4.1 & 3.7 & 2.1 & 1.8 & 2.4 & 2.4 & 10.3 & 22.7 & 2.2 \\
\hline $4 \mathrm{~A}$ & 4.6 & 3.5 & 2.0 & 1.9 & 2.3 & 2.3 & 13.1 & 21.8 & 1.7 \\
\hline 4B & 4.6 & 3.5 & 2.0 & 1.9 & 2.3 & 2.3 & 11.0 & 22.3 & 2.0 \\
\hline $4 \mathrm{C}$ & 4.4 & 3.5 & 2.0 & 1.8 & 2.3 & 2.3 & 12.0 & 22.9 & 1.9 \\
\hline $4 \mathrm{D}$ & 4.5 & 3.7 & 2.0 & 2.0 & 2.3 & 2.3 & 11.8 & 23.3 & 2.0 \\
\hline 1 & 3.8 & 3.6 & 2.2 & 1.7 & 2.7 & 2.7 & 9.7 & 20.7 & 2.1 \\
\hline $\begin{array}{l}\text { Nilai } \\
\text { Rata- } \\
\text { rata }\end{array}$ & 4.2 & 3.6 & 2.1 & 1.8 & 2.4 & 2.4 & 11.2 & 23.0 & 2.1 \\
\hline
\end{tabular}

Tabel 3. Perhitungan dan Perbandingan pada Candi Tebing Gunung Kawi

\begin{tabular}{|l|l|l|l|l|l|l|l|l|l|l|}
\hline & Pembagi & \multicolumn{7}{|c|}{ Hasil Pembagian dimensi EPP } \\
\hline $\begin{array}{l}\text { Kode } \\
\text { Candi }\end{array}$ & $\mathbf{T}(\mathbf{c m})$ & Tk/T & Tb/T & Tkp/T & Lk/T & Lb/T & Lkp/T & Tp/T & Lp/T & Lp/Tp \\
\hline 5A & 1128.5 & 0.25 & 0.27 & 0.48 & 0.58 & 0.41 & 0.41 & 0.09 & 0.04 & 0.44 \\
\hline 5B & 1069 & 0.23 & 0.27 & 0.50 & 0.54 & 0.42 & 0.42 & 0.09 & 0.04 & 0.48 \\
\hline 5C & 1023 & 0.24 & 0.26 & 0.49 & 0.57 & 0.43 & 0.43 & 0.09 & 0.04 & 0.46 \\
\hline 5D & 1013 & 0.25 & 0.27 & 0.48 & 0.57 & 0.43 & 0.43 & 0.10 & 0.04 & 0.43 \\
\hline 5E & 1023.5 & 0.24 & 0.27 & 0.48 & 0.56 & 0.42 & 0.42 & 0.10 & 0.04 & 0.45 \\
\hline 4A & 1046 & 0.22 & 0.29 & 0.49 & 0.53 & 0.43 & 0.43 & 0.08 & 0.05 & 0.60 \\
\hline 4B & 1046.5 & 0.22 & 0.29 & 0.50 & 0.53 & 0.43 & 0.43 & 0.09 & 0.04 & 0.49 \\
\hline 4C & 1007 & 0.23 & 0.28 & 0.49 & 0.56 & 0.44 & 0.44 & 0.08 & 0.04 & 0.52 \\
\hline 4D & 1026.5 & 0.22 & 0.27 & 0.51 & 0.51 & 0.44 & 0.44 & 0.08 & 0.04 & 0.51 \\
\hline 1 & 808 & 0.26 & 0.28 & 0.46 & 0.60 & 0.38 & 0.38 & 0.10 & 0.05 & 0.47 \\
\hline $\begin{array}{l}\text { Hasil Bagi Rata- } \\
\text { rata }\end{array}$ & $\mathbf{0 . 2 4}$ & $\mathbf{0 . 2 8}$ & $\mathbf{0 . 4 9}$ & $\mathbf{0 . 5 5}$ & $\mathbf{0 . 4 2}$ & $\mathbf{0 . 4 2}$ & $\mathbf{0 . 0 9}$ & $\mathbf{0 . 0 4}$ & $\mathbf{0 . 4 9}$ \\
\hline
\end{tabular}

Keterangan :

$\mathrm{T}$ : tinggi keseluruhan candi, Tk : tinggi kaki candi, $\mathrm{Tb}$ : tinggi badan candi, Tkp: tinggi kepala candi, Tp : tinggi pintu semu, Lp : lebar pintu semu, Lk : lebar dasar kaki candi, Lb : lebar dasar badan candi, Lkp : lebar dasar kepala candi.

Berikut adalah hasil dari perhitungan pada Tabel 2 dan Tabel 3. Tinggi keseluruhan (T) adalah 4,2 kali tinggi kaki (Tk); 3,6 kali tinggi badan (Tb); 2,1 kali tinggi kepala (Tkp); 1,8 lebar dasar kaki (Lk); 2,4 kali lebar dasar badan (Lb); 2,4 kali lebar dasar kepala; 11,2 kali tinggi pintu semu (Tp); dan 23 kali lebar pintu 
semu (Lp). Apabila dirumuskan dalam bentuk perbandingan maka akan didapatkan hasil seperti pada penjelasan berikut.

a. $T=4,2 T k$ atau jika $T: T k=1: 0,24$

b. $T=3,6 \mathrm{~Tb}$ atau jika $\mathrm{T}: \mathrm{Tb}=1: 0,28$

c. $T=2,1$ Tkp atau jika $T: T k p=1: 0,49$

d. $T=1,8 \mathrm{Lk}$ atau jika $\mathrm{T}: \mathrm{Lk}=1: 0,55$

e. $T=2,4 \mathrm{Lb}$ atau jika $\mathrm{T}: \mathrm{Lb}=1: 0,42$

f. $T=2,4 \mathrm{Lkp}$ atau jika $\mathrm{T}: \mathrm{Lkp}=1: 0,42$

g. $T=11,2 \mathrm{Tp}$ atau jika $\mathrm{T}: \mathrm{Tp}=1: 0,09$

h. $T=23 L p$ atau jika $T: L p=1: 0,04$

i. $T p=2,1 \mathrm{Lp}$ atau jika $T p: L p=1: 0,49$

Hasil perbandingan T:Lk menunjukan angka 1:0,55 atau dapat dikatakan T adalah 2 kali Lk. Untuk T:Tk pada hasil pembahasan didapat perbandingan 1:0,24 atau jika dibulatkan T merupakan 4 kali Tk. Perhitungan pada proporsi pintu secara umum Tp adalah 2 kali Lp.

Pembahasan berikutnya adalah pembahasan khusus pada bagian kepala candi. Bagian kepala candi dikatakan sebagai EPP yang mempunyai tingkatan dan memang berbeda dengan badan atau kaki candi. Kepala candi disusun oleh kepala tingkat 1 , kepala tingkat 2 , kepala tingkat 3 , dasar mahkota dan mahkota utama seperti pada Gambar 13. Perhitungan pada kepala candi khusus dibahas pada Tabel 5 dan Tabel 6, sedangkan dimensi setiap EPP kepala candi dibahas pada Tabel 4.

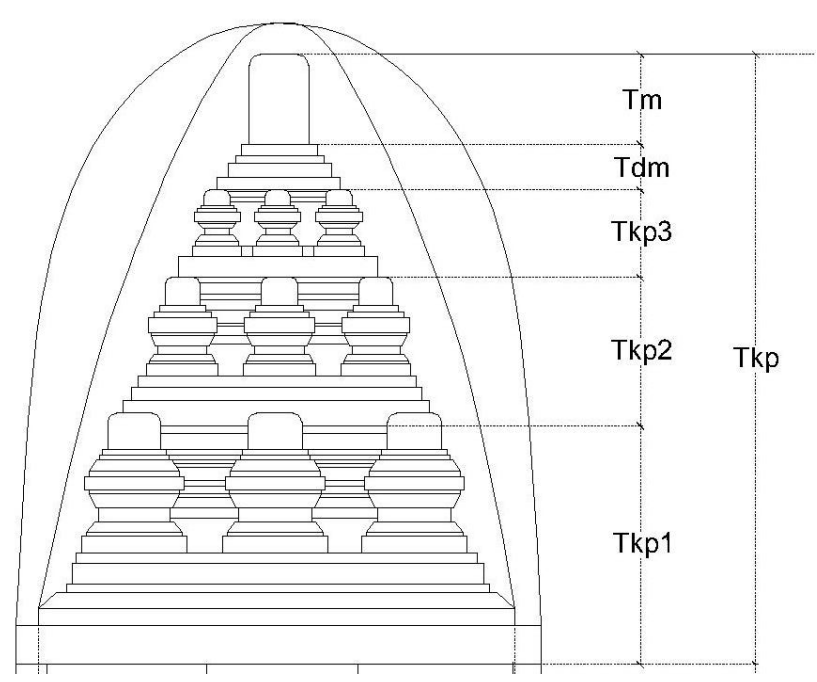

\section{Keterangan :}

Tkp : Tinggi kepala, Tkp1: tinggi kepala tingkat 1, Tkp2: tinggi kepala tingkat 2, Tkp3: tinggi kepala tingkat $3, \mathrm{Tdm}$ : tinggi dasar mahkota, Tm: tinggi mahkota

\section{Gambar 4. Pembagian EPP Kepala Candi Tebing Gunung Kawi} Sumber : Hasil Pengukuran Lapangan, 11 April 2013

Tabel 4. Dimensi EPP pada kepala Candi Tebing Gunung Kawi 


\begin{tabular}{|l|l|l|l|l|l|}
\hline \multirow{2}{*}{$\begin{array}{l}\text { Kode } \\
\text { Candi }\end{array}$} & \multicolumn{5}{|c|}{ Dimensi (cm) } \\
\cline { 2 - 6 } & Tkp1 & \multicolumn{1}{|c|}{ Tkp2 } & Tkp3 & Tdm & Tm \\
\hline 5A & 212 & 131.5 & 78 & 40.5 & 131.5 \\
\hline 5B & 207.5 & 137.5 & 69 & 35.5 & 137.5 \\
\hline 5C & 195 & 132.5 & 61.5 & 40 & 132.5 \\
\hline 5D & 195 & 120 & 63 & 35.5 & 120 \\
\hline 5E & 196.5 & 112.5 & 69.5 & 38 & 112.5 \\
\hline 4A & 210 & 119 & 69 & 43 & 119 \\
\hline 4B & 194.5 & 131 & 76.5 & 40.5 & 131 \\
\hline 4C & 193 & 122.5 & 61.5 & 40.5 & 122.5 \\
\hline 4D & 207.5 & 120.5 & 66 & 42 & 120.5 \\
\hline 1 & 146 & 91.5 & 54.5 & 15 & 91.5 \\
\hline $\begin{array}{l}\text { Rata- } \\
\text { Rata }\end{array}$ & 196 & $\mathbf{1 2 2}$ & $\mathbf{6 7}$ & $\mathbf{3 7}$ & $\mathbf{7 6}$ \\
\hline
\end{tabular}

\section{Keterangan :}

Tkp1: tinggi kepala tingkat 1, Tkp2: tinggi kepala tingkat 2, Tkp3: tinggi kepala tingkat 3, Tdm: tinggi dasar mahkota, Tm: tinggi mahkota

Tabel 5. Perhitungan EPP pada kepala Candi Tebing Gunung Kawi

\begin{tabular}{|l|l|l|l|l|l|}
\hline \multirow{2}{*}{$\begin{array}{l}\text { Kode } \\
\text { Candi }\end{array}$} & \multicolumn{5}{|c|}{ Perhitungan } \\
\cline { 2 - 6 } & Tkp1 & Tkp/Tkp2 & Tkp/Tkp3 & Tkp/Tdm & Tkp/Tm \\
\hline 5A & 2.6 & 4.1 & 6.9 & 13.4 & 6.8 \\
\hline 5C & 2.6 & 3.9 & 7.7 & 15.0 & 6.5 \\
\hline 5D & 2.6 & 3.8 & 8.2 & 12.6 & 6.9 \\
\hline 5E & 2.5 & 4.1 & 7.7 & 13.7 & 6.7 \\
\hline 4A & 2.5 & 4.4 & 7.1 & 13.0 & 6.4 \\
\hline 4B & 2.7 & 4.0 & 7.5 & 12.0 & 7.0 \\
\hline 4C & 2.6 & 4.0 & 8.0 & 12.8 & 6.7 \\
\hline 4D & 2.5 & 4.3 & 7.9 & 12.4 & 6.4 \\
\hline 1 & 2.5 & 4.0 & 6.8 & 24.5 & 6.3 \\
\hline Rata- & 2.5 & 4.1 & 7.5 & 14.1 & 6.0 \\
Rata & & & & & \\
\hline
\end{tabular}

\section{Keterangan :}

Tkp : Tinggi kepala, Tkp1: tinggi kepala tingkat 1, Tkp2: tinggi kepala tingkat 2, Tkp3: tinggi kepala tingkat 3, Tdm: tinggi dasar mahkota, Tm: tinggi mahkota

Tabel 6. Perhitungan EPP pada kepala Candi Tebing Gunung Kawi dengan Tinggi Keseluruhan $(T)$ sebagai pembagi 


\begin{tabular}{|l|l|l|l|l|l|l|}
\hline \multirow{2}{*}{$\begin{array}{l}\text { Kode } \\
\text { Candi }\end{array}$} & Pembagi & \multicolumn{5}{|c|}{ Perhitungan } \\
\cline { 2 - 7 } & $\mathbf{T}$ & Tkp1/T & Tkp2/T & \multicolumn{1}{|c|}{ Tkp3/T } & Tdm/T & Tm/T \\
\hline 5A & 1128.5 & 0.19 & 0.12 & 0.07 & 0.04 & 0.07 \\
\hline 5B & 1069 & 0.19 & 0.13 & 0.06 & 0.03 & 0.08 \\
\hline 5C & 1023 & 0.19 & 0.13 & 0.06 & 0.04 & 0.07 \\
\hline 5D & 1013 & 0.19 & 0.12 & 0.06 & 0.04 & 0.07 \\
\hline 5E & 1023.5 & 0.19 & 0.11 & 0.07 & 0.04 & 0.08 \\
\hline 4A & 1046 & 0.20 & 0.11 & 0.07 & 0.04 & 0.07 \\
\hline 4B & 1046.5 & 0.19 & 0.13 & 0.07 & 0.04 & 0.07 \\
\hline 4C & 1007 & 0.19 & 0.12 & 0.06 & 0.04 & 0.08 \\
\hline 4D & 1026.5 & 0.20 & 0.12 & 0.06 & 0.04 & 0.08 \\
\hline 1 & 808 & 0.18 & 0.11 & 0.07 & 0.02 & 0.08 \\
\hline Rata-Rata & $\mathbf{0 . 1 9}$ & $\mathbf{0 . 1 2}$ & $\mathbf{0 . 0 7}$ & $\mathbf{0 . 0 4}$ & $\mathbf{0 . 0 7}$ \\
\hline
\end{tabular}

Keterangan :

T : Tinggi keseluruhan, Tkp1: tinggi kepala tingkat 1, Tkp2: tinggi kepala tingkat 2, Tkp3: tinggi kepala tingkat 3, Tdm: tinggi dasar mahkota, Tm: tinggi mahkota

Setiap tingkatan pada kepala candi memiliki perbedaan dimensi ketinggian karena memang proporsi bentuk kepala candi yang mengerucut atau mengecil ke bagian ujung atas seperti kepala candi pada umumnya. Berikut adalah hasil perhitungan dari Tabel 5. Perbandingan yang pertama adalah tinggi kepala candi dengan tinggi kepala tingkat 1 atau Tkp/Tkp1 yang mempunyai range nilai dari 2,5-2,7 dengan rata-rata nilai adalah 2,5 atau $T k p=2,5 \mathrm{Tkp} 1$, kemudian perhitungan tinggi kepala dengan tinggi kepala tingkat 2 atau Tkp/Tkp2 dengan range nilai dari 3,8-4,4 dan rata-rata nilai adalah 4,1 sehingga $T k p=4,1 \mathrm{Tkp} 2$. Perhitungan berikutnya adalah Tkp/Tkp3 dengan range nilai mulai dari 6,8-8,2 dan rata-rata nilai adalah 7,5 atau $\mathrm{Tkp}=7,5 \mathrm{Tkp} 3$. Perhitungan yang terakhir dilakukan pada tinggi kepala dan tinggi mahkota utama candi, namun sebelum menuju pada mahkota utama perlu dihitung pula bagian dari dasar mahkota dengan tinggi kepala atau $\mathrm{Tkp} / \mathrm{Tdm}$ dengan nilai rata-rata adalah 14,1 atau $T \mathrm{kp}=14,1 \mathrm{Tdm}$. Perhitungan pada mahkota utama yaitu $\mathrm{Tkp} / \mathrm{Tm}$ mempunyai range nilai 6,0 - 7,0 dan rata-rata nilai adalah 6,6 atau $\mathrm{Tkp}=6,6 \mathrm{Tm}$. Hasil dari Tabel 6 merupakan hasil dari setiap EPP kepala candi yang dibagi dengan tinggi kepala (Tkp) sehingga dapat ditentukan nilai perbandingan Tkp dan rata-rata EPP kepala candi sebagai berikut:

Tkp $=2,5$ Tkp1 atau jika $T:$ Tkp1 $=1: 0,19$

Tkp $=4,1$ Tkp2 atau jika $T:$ Tkp2 $=1: 0,12$

Tkp $=$ 7,5 Tkp3 atau jika $\mathrm{T}:$ Tkp3 $=1: 0,07$

$\mathrm{Tkp}=14,1 \mathrm{Tdm}$ atau jika $\mathrm{T}: \mathrm{Tdm}=1: 0,04$

$\mathrm{Tkp}=6,6 \mathrm{Tm}$ atau jika $\mathrm{T}: \mathrm{Tm}=1: 0,07$

Jika hasil dari perbandingan setiap EPP dengan tinggi keseluruhan (T) di transfomasikan dalam bentuk gambar, dimana $T$ yang bernilai 1 dikalikan 100 begitu pula dengan hasil perbandingan lain yang dikalikan 100 maka akan didapatkat proporsi seperti pada Gambar 14. 

a. $\mathrm{T}: \mathrm{Tk}=100: 24$
b. $\mathrm{T}: \mathrm{Tb}=100: 28$
c. $T: T k p=100: 49$
d. $T: L k=100: 55$
e. $T: L b=100: 42$
f. $T: \operatorname{Lkp}=100: 42$
g. $T: T p=100: 9$
h. $T: L p=100: 4$
i. $T: T k p 1=100: 19$
j. $\quad T: T k p 2=100: 12$
k. T : Tkp3 $=100: 7$
l. $T: T d m=100: 4$
m. $\mathrm{T}: \mathrm{Tm}=100: 7$

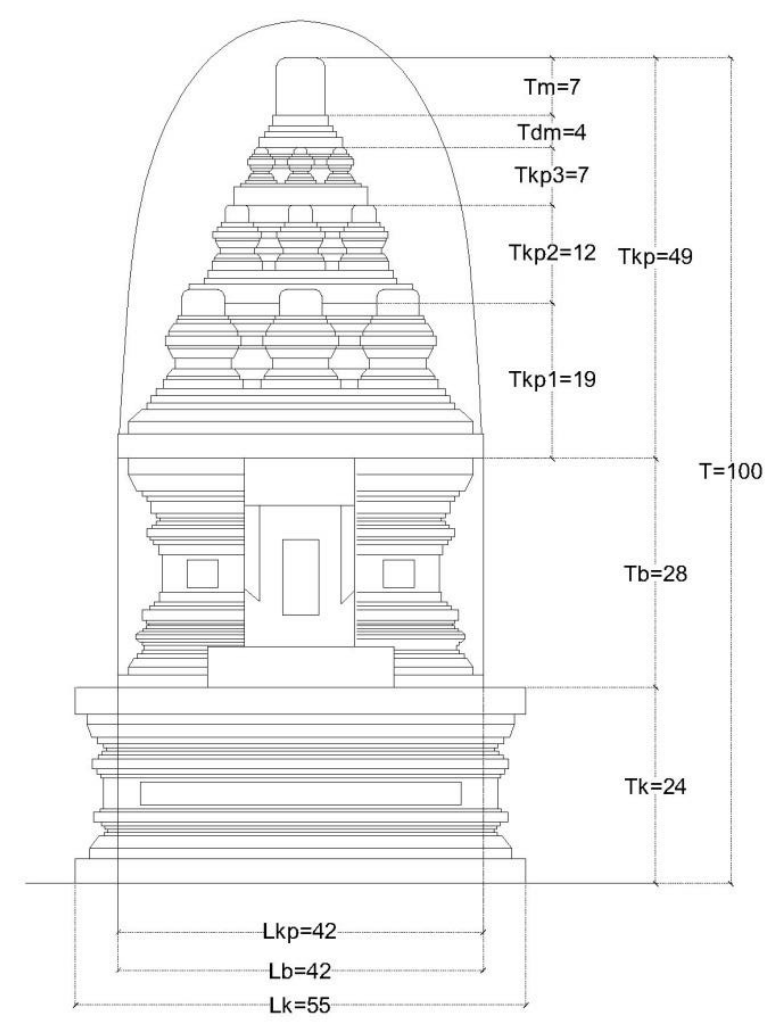

Gambar 5. Hasil perhitungan Proporsi Pada Candi Tebing Gunung Kawi Sumber : Hasil Analisis Raka Gunawarman, 2013

\section{Penutup}

EPP pada Candi Tebing Gunung Kawi secara garis besar terbagi menjadi tiga bagian utama yaitu kaki, badan dan kepala. Detail EPP setiap bagian kaki, badan dan kepala masing-masing terdiri dari perbingkaian bawah, tubuh dan perbingkaian atas. Hasil perhitungan proporsi candi menunjukan hasil bahwa tinggi keseluruhan candi adalah 2 kali lebar kaki (Lk) atau bisa juga 2 kali tinggi kepala (Tkp). Dalam teori manasara-silpasastra berkaitan dengan proporsi antar lebar dan tinggi terdapat lima pembagian perhitungan proporsi yaitu santika, paushtika, parshnika/jayada, adbhuta, dan sarvakamika. Santika mempunyai arti saat tinggi dari bangunan adalah $21 / 4$ dari lebar bangunan, paushtika adalah saat 
dimana tinggi bangunan merupakan 2 kali dari lebar bangunan, parshnika/jayada adalah saat tinggi bangunan adalah $13 / 4$ dari lebar bangunan, adbhuta adalah saat tinggi bangunan adalah $1 \frac{1}{2}$ dari lebar bangunan dan sarvakamika adalah saat tinggi bangunan adalah 11/4 dari lebar bangunan (Acharya, 1927:41). Berdasarkan teori tersebut dapat disimpulkan pula bahwa perhitungan proporsi antara lebar dan tinggi pada Candi Tebing Gunung Kawi termasuk ke dalam paushtika .

\section{Ucapan Terima Kasih}

Penelitian ini dibuat dalam rangka mengikuti hibah penelitian dosen pemula Kementrian Riset, Teknologi, dan Pendidikan Tinggi Republik Indonesia tahun pelaksanaan 2017, yang juga tentunya sudah didanai secara penuh oleh Kementrian Riset, Teknologi, dan Pendidikan Tinggi Republik Indonesia. Dalam penulisan dan penyelesaian penelitian ini, tentu tidak akan bisa berjalan dengan lancar jika tidak ada dukungan dari Fakultas Teknik Universitas Warmadewa khususnya pada Jurusan Arsitektur yang sangat mendukung penuh proses penelitian ini. Ucapan terima kasih juga diucapkan kepada lembaga penelitian Universitas Warmadewa yang sudah memberikan klinik-klinik proposal penelitian dan sejenisnya untuk menambah wawasan dan keterampilan dalam menulis.

\section{Daftar Pustaka}

Acharya, Prasanna Kumar. 1927. Indian Architecture According To ManasaraSilpasastra. London; New York; Calcuta; Madras : The Oxford University Press.

Atmadi, Parmono. 1979. "Beberapa Patokan Perancangan Bangunan Candi : Suatu Penelitian Melalui Ungkapan Bangunan Pada Relief Candi Borobudur" (disertasi). Yogyakarta : Universitas Gajah Mada.

Emzir. 2012. Metodologi Penelitian Pendidikan : Kuantitatif dan Kualitatif. Cetakan ke-6. Jakarta : PT. Rajagrafindo Persada.

Kaulacara, Ramacandra. 1966. Silpa Prakasa: Medieval Orissan Sanskrit Text On Temple Architecture. Terjemahan Alice Boner dan Sadasiva Rath Sarma. Leiden : E.J. Brill.

Mardiwarsito,L. 1986. Kamus Jawa Kuna (Kawi) - Indonesia. Cetakan III. Ende Flores : Nusa Indah.

Provinsi Bali, Disbud. 1987. Pura Besakih. Denpasar: Dinas Kebudayaan Pemerintah Provinsi Bali.

Soekmono, R. 1988. Pengantar Sejarah Kebudayaan Indonesia 2. Cetakan kelima. Yogyakarta : Kanisius. 